\title{
Product Placement in TV Shows: The Effect of Consumer Socialization Agents on Product Placement Attitude and Purchase Intention
}

\author{
Eunseon Kwon, University of Missouri, USA \\ Jong-Hyuok Jung, Texas Christian University, USA
}

\begin{abstract}
In recent years, many studies have investigated consumers' attitudes toward product placement in media content, such as movies and TV shows. However, few studies have explored the influence of peer communication and media consumption on product placement attitudes and purchase intention of products that displayed in TV shows. Drawing on the consumer socialization framework, the current study investigates product placement attitudes and behavioral intentions via online survey. Moreover, this research examined the impact of reading online consumer review of placed products as an extended socialization variable. Results show that peer communication, a socialization agent, is strongly related to both product placement-related attitudes and purchase intentions. Findings also indicate that reading online consumer reviews of placed products is a good predictor of consumers' purchase intentions.
\end{abstract}

Keywords: Product placement, Attitude change, Purchase intention, Consumer socialization framework. 


\section{Introduction}

Companies are often frustrated by devices, such as digital video recorders (DVRs), which allow consumers to skip advertisements on TV, thus weakening once effective tool to promote brands or products. According to a Nielsen report, more than $71 \%$ of U.S. households use DVRs (The Cab, 2012). In order to attract consumers' attention, advertisers have purposefully placed products or brand names into movies or TV scripts (Ferraro \& Avery, 2000; Russell \& Belch, 2005). In 2011, advertisers spent approximately $\$ 3.8$ billion for product placement in TV shows and movies, and this expenditure is expected to be more than $\$ 14$ billion by 2014 (Hampp, 2010).

Although product placement is widely employed in various media contents such as movies, music videos, songs, and video games (Balasubramanian, Karrh, \& Patwardhan, 2006; Ferraro \& Avery, 2000; Russell, 2002; Sung \& de Gregorio, 2008), the study of consumers' attitudes toward product placement is still in its infancy. Instead, previous studies have focused heavily on consumers' attitudes toward advertising(Bush, Smith, \& Martin, 1999; Smith \& Moschis, 1984), such as the impact of consumers' demographic variables and social factors that influence attitudes toward advertising. However, there is limited understanding of consumers' attitudes toward product placement. Product placement attitudes among AfricanAmerican and Caucasian adolescents(Bush et al., 1999; Choi \& La Ferle, 2004) and consumers' attitudes toward product placement in movies (Gupta \& Gould, 1997; de Gregorio \& Sung, 2010) are well documented; however, little is known about consumers' general attitudes toward product placement in TV shows.

This study employed a consumer socialization framework to analyze consumers' product placement attitudes and behavioral intentions. Consumer socialization is a well-known theoretical framework that can be used to analyze the impact of socialization variables on attitudes toward product placement and subsequent behavior. Thus, the current study seeks to address the following research question: How do consumer socialization agents (peer communication, online consumer reviews, watching TV shows) affect consumers' attitudes toward product placement in TV shows and their behavioral intentions? 


\section{Literature Review}

To explore the factors that influence consumers' behavioral intentions and attitudes toward product placement in TV shows, the following sections review consumer socialization theory as well as peer communication, online consumer review, media usage, attitude toward product placement, and purchase intentions.

\section{Consumer Socialization Theory}

The term socialization has been discussed by scholars for several decades (Blythe, 1997). Merton and Kitt (1950) defined socialization as processes affecting one's current and final behavior, often called anticipatory socialization (Merton \& Kitt, 1950). Derived from this concept, Ward (1974) defined consumer socialization as the "process by which young people acquire skills, knowledge, and attitudes relevant to their functioning as consumers in the marketplace" (p.2).Various theories (e.g., social learning, cognitive development) have been used to explain the process of consumer socialization as it relates to an individual's life cycle. One of the most commonly utilized theoretical frameworks to explain consumer socialization process issocial learning theory (Bandura, 1977; Bush et al., 1999).

According to social learning theory, an individual is a passive participant in the learning process, acquiring and developing attitudes and beliefs through interaction (Bush et al., 1999). This theory posits that 'others' are the socialization agents (people, institutions, and organizations) which directly shape the individual's attitudes and behaviors, outcomes of the socialization process (McLeod \& O’Keefe, 1972). Previous studies defined peers and parents as socialization agents of TV advertising (Moschis \&Churchill, 1978; Ward \& Wackman, 1971). Consumer socialization studies indicate that individuals acquire consumer skills, attitudes, and knowledge through communicating with and observing socialization agents (Bush et al., 1999). These skills are often referred to as purchase intention, attitudes toward prices, and economic motivations. In this study, socialization agents (peer communication, watching TV shows) and outcomes (product placement attitude and purchase intention) are used to explain consumer socialization in the context of product placement.

\section{Conceptual Framework}

Based on previous studies on consumer behavior (socialization and attitudes), a conceptual framework is proposed for this study (see Figure 1). This section discusses how previous 
authors have described different variables in this conceptual framework. In addition, the proposed hypotheses are followed by a discussion of each variable.

\section{Peer Communication}

Consumers are affected by multi-level influences when they choose a product (Narayan, Rao, $\&$ Saunders 2011). Consideration includes attributes of the product, word-of-mouth communication, or online reviews to make a final decision. This is called peer influence. The consumer socialization theory posits that consumption-related communication between consumers transmits attitudes and behavior changes (Bush et al.,1999; Moschis \& Churchill 1978). In this study, peer communication is defined as conversation among peers (family members, colleagues, friends, etc.) about consumption-related topics of product placement in TV shows.

Previous studies on the role of social communication in consumer behavior found that consumers' attitudes and purchase intentions are influenced by peer communication. For example, Ward and Wackman (1971) found that communication between youth and their parents influence purchase intentions and exposure to commercials. This is an important finding because adolescents' consumer behavior often continues throughout their lives. Therefore, family communication about purchase behavior develops one's role as a consumer, even with the increased number of expected social roles as they age. Another study (Bush et al., 1999)explored how peer communication, particularly with friends and parents, affects consumers' attitudes toward advertising among college students. Results of this study suggest that peer communication played a major part in forming consumers' general attitudes toward advertising, especially toward general advertising on TV (not exclusively product placement). It only pertained to two specific groups, namely African-American and Caucasians.

As previously discussed, a number of studies have been conducted on the influence of peers as a reference source on consumer attitudes or purchase behaviors. With that in mind, consumers purchase intentions or attitudes toward product placement on TV may be due to peer influences, such as word-of-mouth-communication. Therefore, the following hypotheses can be formulated:

H1a: Consumers conversation about product placement in TV shows with their peers positively influences consumers' attitudes toward product placement. 
H1b: Consumers conversation about product placement with their peers positively influences consumers' purchase intention toward the placed products.

\section{Online Consumer Review for Placed Products}

Consumers are influenced by peers' opinions about products or their consumption behavior. However, emergence of the Internet has expanded the conceptualization of 'peers'. With regard to traditional peer influence, previous studies have explored consumers' interaction between friends and family members (Johnson, Rickel, \& Lester, 2000; Mears, Ploeger, \& Warr, 1998). Through the Internet, consumers can find other people's reviews on products or services in e-commerce websites such as Amazon.com. The popularity of e-commercehas made these websites a significant presence in the online marketplace (Gruen, Osmonbekov, \& Czaplewski, 2006; Park \& Lee, 2009). Although the reviews in these websites are by strangers, consumers may find information valuable and consider these individuals as peer influencers (Kim, Mattila, \& Baloglu, 2011).

Previous studies have examined consumers' motivation for using online consumer reviews in various contexts (Chen \& Xie; 2008; Goldsmith \& Horowitz, 2006; Kim et al., 2011; Park \& Lee; 2007). For example, Chen and Xie (2008) found that use of online consumer reviews were: to gain product knowledge, to validate product choice, and to make correct purchase decisions. By interacting with online peers, consumers acquire new knowledge and skills relevant in the online marketplace, which is at the core of consumer socialization theory. Regarding purchase intention, consumers were more likely to purchase products which have high quality reviews from high quantity of consumers (Park, Lee, \& Han, 2007) when they spend relatively more time online (Zhu \& Zhang, 2010). Moreover, negative product reviews are more powerful predictors of consumers' purchase intention than positive reviews since they determine product quality (Sen \& Lerman, 2007).According to Weinberg and Davis (2005), consumers use online reviews when they have sufficient interest in product. Therefore, it is plausible to assume that consumers who read more online reviews for placed products are more likely to be interested in it if placed in TV shows.

A recent report (Flacy, 2012) revealed that approximately 92\% of online reviews are positive contains favorable product information or higher product evaluation score. Perhaps, online consumer reviews of placed products are included in that $92 \%$. Thus, by observing online 
peers' positive product review of placed products, consumers might believe that TV shows employ great products for shows, which in turn lead consumers to have positive placement attitudes. In addition, based on what Park and Lee (2007) found, it is plausible that consumers who read more online product reviews of placed products would be more likely to have stronger purchase intentions for them.

Currently, there is a lack of research on the relationship between online consumer reviews of placed products and purchase intention as well as product placement attitude. Thus, the following hypotheses can be formulated:

H2a: Reading online consumer reviews of placed products will positively influence consumers' attitudes toward product placement.

H2b: Reading online consumer reviews of placed products will positively influence consumers' purchase intentions for the placed products.

\section{Media Usage: Watching TV Shows}

The consumer socialization framework considers media usage as an important source of consumption-related beliefs, attitudes, and behavior changes. While peer communication directly affects one's attitudes and behaviors, media content indirectly affects this relationship. It is widely-held belief that watching TV shows contributes to the learning processes of a wide range of consumer orientations (Choi \& La Ferle, 2004).With regard to media impact, advertising has been given attention by scholars because of its specific focus on consumption-oriented messages (Ward, 1974). In addition, repeated exposure to advertisements influences consumers to agree with consumption-related ideas and desires. Zajonc (1968) explained that repeated exposure to a particular stimulus often equates with preference. Specifically, mere exposure theory proposes that repeated exposure to novel stimuli produces positive attitudes. A number of studies (Bush et al., 1999; Karrh, Frith, \&Callison, 2001; Lehu, 2007) found that repeated exposure to product placement in media contents results in consumers having positive attitudes toward the object, even leading to certain behavioral outcomes.

Bush and colleagues (1999) explored the influence of TV watching on African-American and Caucasian consumers' attitudes toward advertising. Results showed that heavy TV viewing yielded more positive attitudes toward advertising. Frequency of movie watching was also 
found to be a strong predictor of positive product placement attitude as well as purchase intention (de Gregorio \& Sung, 2010). However, consumers' positive attitudes are limited to certain products, media genres, and product placement tactics (Brennan, Schutte, \& Moos,1999; Gupta \&Gould, 1997; Ong, 2004;de Gregorio \& Sung, 2010). For example, Gupta and Gould (1997) found that media audiences had negative attitudes toward the placement of ethically charged products, such as guns and tobacco. In their study, the majority of respondents showed positive product placement attitudes but expressed low tolerance toward problematic products.

Although previous investigations on product placement attitudes were focused on specific topics or media genre, limited studies have conducted on product placement in TV shows in general. According to a recent report (Weinberger \& O'Dell, 2012), an average of 16 product placement occurrences were found in one episode during primetime TV shows in 2011. Moreover, Nielsen reported that the number of product placement occurrences has increased by almost nine percent compared to 2010 . Consumers who frequently watch TV shows are more likely to be exposed to abundant product placements, which affect their attitude and purchase intention. Therefore, the following hypotheses can be formulated:

H3a: Individual's frequency of watching TV shows will positively influence consumers' attitudes toward product placement on TV.

H3b: Individual's frequency of watching TV shows will positively influences consumers' purchase intentions for the placed products. 
Figure 1: A conceptual model of consumer socialization and product placement attitude and behavior outcome

Independent Variables Dependent

Variables

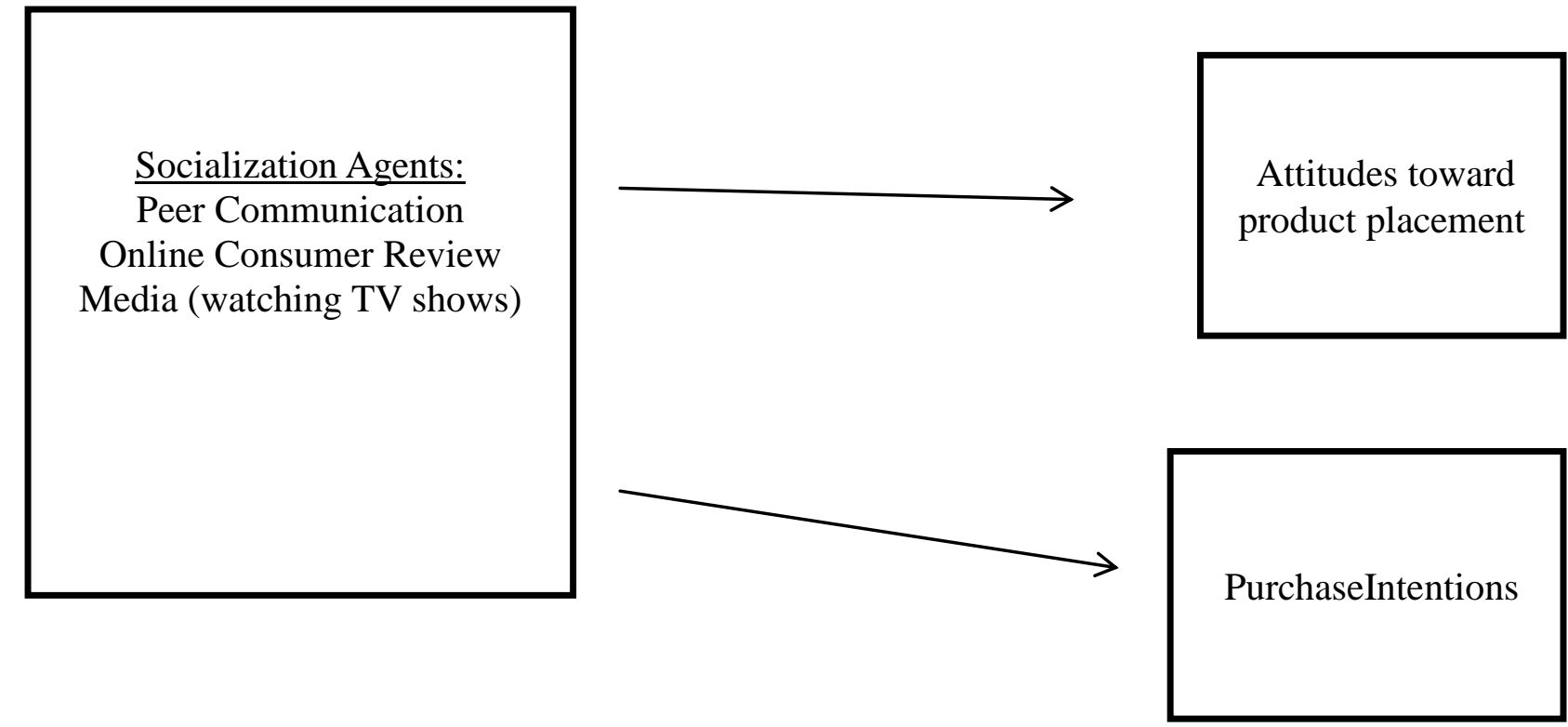

\section{Method}

\section{Sample and Procedure}

The current study employed an online survey. Initially, 600 college students were recruited and they received an invitation e-mail via instructors. A total of 209 students agreed to participate in this study, resulting in a response rate of 38\%.Among the 209 participants, 160 (77.7\%) were females and $46(22.3 \%)$ were males. Approximately $81 \%$ of the respondents were aged 18-24;14.4\%, 25-35; and 4.5\%,36 and older. Caucasian students comprised 74.8\% of the sample, followed by Asian or Pacific Islander (10.7\%), Hispanic (5.7\%), African American (5.0\%), Native American or Alaskan native (1.9\%), and other ethnicity (1.9\%). Additional demographic characteristics of the respondents are shown in Table 1. 
Table 1: Demographic Profile of the Sample (N=209)

\begin{tabular}{|c|c|c|c|}
\hline & & Frequency & Percent \\
\hline \multirow[t]{2}{*}{ Gender } & Female & 160 & 77.7 \\
\hline & Male & 46 & 22.3 \\
\hline \multirow[t]{3}{*}{ Age Group } & $18-24$ & 163 & 81.1 \\
\hline & $25-35$ & 29 & 14.4 \\
\hline & Over 36 & 9 & 4.5 \\
\hline \multirow[t]{4}{*}{ Education Level } & High School & 2 & 1.3 \\
\hline & $\begin{array}{l}\text { Some College or Attending } \\
\text { College }\end{array}$ & 128 & 80.0 \\
\hline & Bachelor's Degree & 13 & 8.1 \\
\hline & Attending Graduate School & 17 & 10.6 \\
\hline \multirow[t]{5}{*}{ Income Level } & Less than $\$ 24,999$ & 44 & 28.0 \\
\hline & $\$ 25,000-\$ 49,999$ & 28 & 17.9 \\
\hline & $\$ 50,000-\$ 99,999$ & 30 & 19.1 \\
\hline & $\$ 100,000-\$ 149,999$ & 32 & 20.4 \\
\hline & Over $\$ 150,000$ & 23 & 14.6 \\
\hline \multirow[t]{6}{*}{ Ethnicity } & Caucasian & 119 & 74.8 \\
\hline & African American & 8 & 5.0 \\
\hline & $\begin{array}{l}\text { Native American or Alaskan } \\
\text { Native }\end{array}$ & 3 & 1.9 \\
\hline & Asian or Pacific Islander & 17 & 10.7 \\
\hline & Hispanic & 9 & 5.7 \\
\hline & Others & 3 & 1.9 \\
\hline
\end{tabular}




\section{Measurement and Reliability}

Measurement items used in the study were drawn from previous literature. Respondents were asked to answer four sets of questions measuring attitude toward product placement in TV shows, purchase intentions for placed products, time spent watching TV shows, peer communication about product placement, and demographic information.

Attitudes toward product placement in TV shows. Several studies on consumers' attitudes toward product placement are based on the questionnaire used by Gupta and Gould (1997). However, the questionnaire used in this study measured different dimensions of consumers' attitudes toward product placement. Since this study attempted to assess consumers' general attitudes toward product placement in TV shows, the survey questionnaire was modified according to Muehling's (1987) three-item attitude scale toward advertising (e.g., bad versus good; negative versus positive; unfavorable versus favorable). One additional item (unlikable versus likable) was added to the questionnaire. These items were measured along a five-point Likert scale, ranging from "Strongly Disagree" (1) to "Strongly Agree" (5). The four item scale was found to be a reliable measure $(\alpha=.97)$.

Purchase intentions. Questions regarding consumers' purchase intentions for placed products were modified from the four-item scale used in Heijden and Verhagen (2004).Statements in the current study included "I will buy placed products, which I saw in TV shows, in the next two weeks," "I will buy placed products, which I saw in TV shows, in the next two months," and "I will buy placed products, which I saw in TV shows, when I need the products." These three items were averaged to form a "purchase intention" scale with a reliability coefficient of .77.

Media consumption. This variable was operationalized as the time spent watching TV shows on a daily basis. Respondents were asked to indicate how much time they typically spent watching TV shows in a day.

Peer communication about product placement. Consumers' peer communication about product placement was assessed through six-item, five-point Likert scale developed by Moschis and Churchill's (1978). (e.g., "I ask my peers for advice about buying things," "I and my peers talk about things I see or hear advertised," "I and my peers often talk about 
product placement in TV shows," and "I and my peers often talk about products used by TV characters in TV shows.") The four items were found to be a reliable measure $(\alpha=.67)$.

Reading online consumer reviews of placed products. Reading online consumer reviews of placed products were measured on a scale developed by Bearden, Netemeyer, and Teel (1989), which explored consumers' social susceptibility to interpersonal influence. Statements asked respondents' motivation for reading online consumer reviews of placed products (e.g., "I read online consumer reviews of placed product because my peers said the product is good). The five-item, five-point Likert scale questionnaires were found to be reliable $(\alpha=.89)$. As shown in Table 2, all variables were found to be reliable; Cronbach's alphas ranged from .67 to .97 .

Table 2: Descriptive Statistics of Key Variables

\begin{tabular}{|c|c|c|c|c|c|c|c|}
\hline Variables & $\begin{array}{l}\text { Mea } \\
\mathrm{n}\end{array}$ & $\mathrm{SD}$ & Min & $\begin{array}{l}\mathrm{Ma} \\
\mathrm{x}\end{array}$ & $\begin{array}{l}\text { Cronbach's } \\
\text { alpha }\end{array}$ & $\begin{array}{l}\text { Measurement } \\
\text { scale }\end{array}$ & $\begin{array}{l}\# \text { of } \\
\text { items }\end{array}$ \\
\hline Placement & 3.14 & .93 & 1.00 & 5.0 & .97 & 5-pt Likert & 4 \\
\hline Attitude & & & & 0 & & & \\
\hline \multirow[t]{3}{*}{ Purchase Intention } & 2.77 & .77 & 1.00 & & .77 & 5-pt Likert & 3 \\
\hline & & & & 5.0 & & & \\
\hline & & & & 0 & & & \\
\hline \multirow[t]{2}{*}{ Peer Communication } & 3.27 & .67 & 1.25 & 5.0 & .67 & 5-pt Likert & 4 \\
\hline & & & & 0 & & & \\
\hline Consumer & 2.26 & .74 & .80 & 4.0 & .89 & 5-pt Likert & 5 \\
\hline Review & & & & 0 & & & \\
\hline
\end{tabular}

\section{Results}

\section{Regression Analyses}

Multiple regression analyses were employed to further explore the relative influence of the independent variables (i.e. peer communication, media usage, online product review) on the dependent variables (i.e., attitude toward PPL in TV; behavioral intention). Table 3 summarizes the result of the regression analysis, used to predict attitudes toward product placement in TV shows. The regression model was found to be significant $\left(R^{2}=.11, F(3,192)\right.$ $=7.53, p<.001)$. Peer communication $(\square \square \square \square \square 22, p<.001)$ was found to be a significant 
predictor of attitudes toward product placement in TV shows. Additionally, media usage was found to be a marginally significant predictor ( $\square \square \square \square \square 12, p=.07$ ) of attitudes toward product placement in TV shows. Inconsistent with our predictions, reading online consumer review was not found to be a significant predictor of attitude toward product placement in TV shows, thus providing support for $\mathrm{H} 1 \mathrm{a}$, but failing to provide support for $\mathrm{H} 2 \mathrm{a}$ and $\mathrm{H} 3 \mathrm{a}$.

Table 4 shows the results of the regression analysis predicting consumers' intentions to purchase products featured in product placement on TV. The $F$-test of the model shows significant result $\left(R^{2}=.302 F(3,192)=27.66, p<.001\right)$, which further confirms the influence of three predictors (i.e., peer communication, media usage, online product review) and consumers' intention to purchase products in TV produce placement. Online review $(\square \square \square \square \square 33, p<.001)$ and peer communication $(\square \square \square \square \square 29, p<.001)$ were found to be significant predictors of purchase intention. Additionally, media usage was found to be marginally significant $(\square \square \square \square \square 10, p=.09$ ) in predicting purchase intention. These results provide support for $\mathrm{H} 1 \mathrm{~b}$ and $\mathrm{H} 2 \mathrm{~b}$.

Table 3: Regression Analysis for Predicting Attitude Toward Product Placement in TV

\begin{tabular}{lclr}
\hline & $\begin{array}{l}\text { Regression } \\
\text { Coefficient (b) }\end{array}$ & $\begin{array}{l}\text { Standardized Regression } \\
\text { Coefficient (beta) }\end{array}$ & $\mathrm{t}$ \\
\hline Constant & 1.67 & .22 & $2.78^{* *}$ \\
Peer Comm. & .31 & .10 & 1.29 \\
Online Review & .13 & .13 & .70 \\
Media Usage & .09 & & \\
$R^{2}$ & .11 & & \\
$F$ & $7.53 * * *$ & & \\
\hline
\end{tabular}

Note. $* P<.05, * * P<.01 * * * P<.001$ 
Table 4: Regression Analysis for Predicting Purchase Intention

\begin{tabular}{lccc}
\hline & $\begin{array}{l}\text { Regression } \\
\text { Coefficient (b) }\end{array}$ & $\begin{array}{l}\text { Standardized Regression } \\
\text { Coefficient (beta) }\end{array}$ & $\mathrm{t}$ \\
\hline Constant & .82 & .29 & $4.05^{* * *}$ \\
Peer Comm. & .33 & .33 & $4.59^{* * *}$ \\
Online Review & .34 & .10 & 1.66 \\
Media Usage & .06 & & \\
$R^{2}$ & .30 & & \\
$F$ & $27.66^{* * *}$ & & \\
\hline
\end{tabular}

Note. ${ }^{*} P<.05, * * P<.01 * * * P<.001$

\section{Discussion and Implications}

Although an increasing number of studies have explored product placement and related consumer behavior, there is understanding of the social factors that interact with consumers' product placement attitudes and purchase intentions. Results of the current study suggest that consumer socialization framework is helpful to expand the knowledge of product placement in TV shows and related consumer behavior.

Findings confirm the results of previous studies which showed that consumers who have more conversation with peers about product in social networking sites (Xia, Yu, \& Wei; 2012) or placed products in movies (de Gregorio \& Sung, 2010) are more likely to have favorable product placement attitudes. Taking this in account, advertisers would be successful if product placement actually influenced communication about placed products. For example, advertisers would be more successful if they placed products in TV shows which targeted young adults who are considered to be the most tech-savvy and spends a significant amount of time online (Pressler \& Rovzar, 2008).

One of the most successful shows targeted at young adults 'Gossip Girl' not only has great ratings, but also successfully utilizes product placement. A recent article from NY Magazine explains that since the first season of the show, 'Gossip Girl' fans have been posting a lot of information about placed products on fan sites (Pressler \& Rovzar, 2008). One of the biggest sponsors of this show, Verizon, stated that they see more incoming young consumers since they placed products in the show (Steinberg, 2007). Sponsorship of 'Gossip Girl' may not be 
the only reason for the increase in the number of Verizon customers, but it is plausible to assume that product placement was an effective strategy to entice them. Therefore, product placement in TV, movies, and online product discussion may have great socializing impact for consumers.

Unlike previous consumer socialization research, another finding of the current study suggests that reading online consumer reviews is a significant predictor of consumers' purchase intention for placed products. Previous research suggested that consumers go online to gather product attribution and price information before making purchase decisions (Goldsmith \& Horowitz, 2006; Kim et al., 2011; Schiffman \& Kanuk, 1987; Sen \& Lerman, 2007; Zhu \& Zhang, 2010). Furthermore, the emergence of the Internet has expanded and modified the concept of 'peers'. Although online consumer reviews are from strangers, consumers consider them as peers and rely on their opinions. Moreover, the majority of online product reviews are positive (Flacy, 2012) which would include placed products and eventually lead to purchase behavior. Therefore, practitioners should utilizeonline consumer reviews and product placement. For example, $\mathrm{MBC}$, one of the biggest Korean broadcasting companies, provides an online service called 'One more TV'. This website provides VOD (Video-on Demand) service for all programs as well as placed products information (e.g., brand name, product price) when they play for the VOD service. Furthermore, with a single click, consumers are directly linked to online shopping websites for placed products anytime. These websites provide consumers reviews and more detailed product information. According to MBC (2012), advertisers who placed product information in the VOD service see an increasing number of consumers visiting online shopping websites, which might lead to an increasein sales. The success of 'One more TV' was enabled by comprehensive research of consumer needs and effectiveness of product placement in TV shows.

Although the current study confirmed the relationship between peer communication and product placement attitudes and purchase intentions, it was not able to predict the influence of watching TV shows on product placement attitudes and purchase intentions. There are several explanations for these results. One possible reason is the level of distraction watching product placement in TV shows. Consumers are more likely to be distracted while watching a TVshow than watching a movie in theater. The nature of theater limits consumers from distraction and forces them to concentrate to movies. However, consumers canchange 
channels or talk to others while watching TV. Perhaps consumers who watch TV shows are less likely to be exposed to product placement than those in the theater. Hence, consumers' attitudes and purchase intention about product placement may differ by the medium of exposure for product placement.

\section{Limitations and Issues for Future Research}

Some limitations of the study should be noted and explored in future research. First, this research is limited to consumers' TV show consumption through TV only. In other words, consumers enjoy watching TV shows through various media devices such as tablet computers, mobile phones, and the Internet. These novel media environments provide placed products' information to consumers through more convenient and comprehensive ways. Therefore, consumers who use various media devices are more likely learn about placed products, which may increase their curiosity and purchase intentions. Future researchers need to assess whether consumers' attitudes and purchase intentions differ by media platform.

Second, the current study found that watching TV shows affects consumers' product placement attitudes and purchase intentions. However, the study explored consumers' general experience of product placement in TV shows. Specifically, some products are both positively and negatively portrayed in the shows. Moreover, it is possible that consumers get more intrigued by certain products, which are used by their favorite TV characters. Thus, it is critical to assess how consumers are affected by different portrayals of product placement. In addition, marketers need to actively manage product portrayals in the shows to ensurethat consumers have favorable attitudes toward the product, which in turn may result in increased purchase intentions for the placed product.

Finally, in future studies, data should be collected from a more demographically diverse sample. Results from this study were drawn from a small and homogeneous sample. They are mainly young, Caucasian, and female students in the U.S. Although younger groups of consumers spend more time watching TV (Perse, 1986) and spend more time online, a more balanced demographic sample would allow a more insightful analysis. 


\section{References}

Balasubramanian, S. K., Karrh, J. A., \& Patwardhan, H. (2006). Audience response to product placements: An integrative framework and future research agenda. Journal of Advertising, 35(3), 115-141.

Bearden, W. O., Netemeyer, R. J., \&Teel, J. E. (1989).Measurement of consumer susceptibility to interpersonal influence.Journal of Consumer Research, 15 (4), 473481.

Blythe, J. (1997), The essence of consumer behaviour. Essex, England: Prentice Hall.

Brennan, P. L.,Schutte, K. K., \& Moos, R. J. (1999).Reciprocal relations between stressors and drinking behavior: A three-wave panel study of late middle-aged and older women and men.Addiction. 94(5), 737-749.

Bush, A., Smith, R., \& Martin, C. (1999). The influence of consumer socialization variable on attitude toward advertising: A comparison of African-Americans and Caucasians. Journal of Advertising, 28(3), 13-24.

Chen, Y. \& Xie, J. (2008). Online Consumer Review: Word-of-Mouth as a new element of marketing communication mix. Management Science, 54(3), 477-491.

Choi, S. M., \& La Ferle, C. (2004). Convergence across American and Korean young adults: Socialisation variables indicate the verdict is still out. International Journal of Advertising 23(4), 479-506.

de Gregorio, G., \& Sung, Y. (2010). Understanding attitudes toward and behaviors in response to product placement. Journal of Advertising, 39(1), 29-96.

Goldsmith, R. E., \& Horowitz, D. (2006). Measuring motivations for online opinion seeking. Journal of Interactive Advertising, 6(2), 1-16.

Flacy, M. (2012), Amazon merchant caught bribing customers for five-star reviews. Digital Trends, http://www.digitaltimes.com

Ferraro, R., \& Avery, R. (2000). Brand appearances on prime-time Television. Journal of Current Issues and Research in Advertising, 22(2), 1-15.

Gupta, P. B., \& Gould, S. J. (1997). Consumers' perceptions of the ethics and acceptability of product placements in movies: Product category and individual differences. Journal of Current Issues \& Research In Advertising (CTC Press), 19(1), 37.

Gruen, T. W., Summers, J. O., \& Acito, F. (2000). Relationship marketing activities, commitment, and membership behaviors in professional associations. Journal of Marketing, 64(July), 34-49 
Hampp, A. (2010). How miracle whip, plenty of fish tapped Lady Gaga's 'Telephone.' Adage. http:// adage.com/article/madisonvine-news/miracle-whip-plenty-fish-tap-lady-gagas-telephone/142794/

Heijden, H., \&Verhagen, T. (2004). Online store image: conceptual foundations and empirical measurement.Information \& Management. 41(5), 609.

Johnson, L. W., Rickel, J. W., \&Lester, J. C. (2000).Animated pedagogical agents: Face-toface interaction in interactive learning environments. International Journal of Artificial Intelligence in Education 11, 47-78.

Karrh,J. A., Frith, K. T., and Callison, C. (2001).Audience attitudes towards brand (product) placement: Singapore and the United States," International Journal of Advertising. 20(1), 3-24.

Kim, E. E. K., Mattila, A. S., and Baloglu, S. (2011).Effects of gender and expertise of consumers' motivation to read online hotel reviews.Cornell HospitalityQuarterly, 52(4), 399-406.

Lehu, J.(2007). Branded Entertainment: Product Placement \& Brand Strategy in the Entertainment Business. London: Kogan Page.

MBC (2012). Munhwa Broadcasting Corporation. http://www.imbc.com

McLeod, J. M., \& O’Keffe, Jr., G. (1972).The socialization perspective and communication behavior. In Current Perspective in Mass Communication Research, eds. G. Kline and P. Tichenor, Beverly Hills, CA: Sage Publication.

Mears,D. P., Ploeger, M., \&Warr, M. (1998). Explaining the gender gap in delinquency: Peer influence and moral evaluations of behavior.Journal of Research in Crime and Delinquency, 35(3), 251-266.

Merton, R. K., \&Kitt, A. (1950). Contributions to the theory of reference group behavior. Glencoe, Illinois: Free Press.

Moschis, G. P., and Churchill, Jr., G. A. (1978). Consumer socialization: A theoretical and empirical analysis. Journal of Marketing Research. 15(November), 599-609.

Muehling, D, D. (1987). An investigation of factors underlying attitude-toward -advertising in-general. Journal of Advertising. 16(1), 32-40.

Narayan, V., Rao, V. R., \& Saunders, C. (2011). How peer influence affects attribute preferences: A bayesian updating mechanism. Marketing Science, 30(2), 368-384.

Ong, B. S. (2004). A comparison of product placements in movies and Television programs: An online research study.Journal of Promotion Management. 10(1/2), 147-158. 
Park, D. H., \& Lee, J. (2009). eWOM overload and its effect on consumer behavioral intention depending on consumer involvement. Electronic Commerce Research and Applications, 7(4), 386-398.

Park, C., \&, Lee, T. M. (2009). Information direction, website reputation and eWom effect: A moderating role of product type. Journal of Business Research, 62(1), 61-67.

Park, D. H., Lee, J., \& Han, I. (2007). The effect of on-line consumer reviews on consumer purchasing intention: The moderating role of involvement. International Journal of Electronic Commerce, 11(4), 125-148.

Perse, E. M. (1986). Soap opera viewing patterns of college students and cultivation. Journal of Broadcasting \& Electronic Media. 30(2), 175-193.

Pressler, J., \&Rovzar, C. (2008). The genius of Gossip Girl. New York Magazine, http://nymag.com/arts/tv/features/46225/

Russell, C. A. (2002). Investigating the effectiveness of product placements in television shows: The role of modality and plot connection congruence on brand memory and attitude. Journal of Consumer Research, 29(3), 306-318.

Russell, C. A., \&Belch, M. (2005). A managerial investigation into the product placement industry.Journal of Advertising Research. 45(1), 73-92.

Schiffman, D., \& Kanuk, J.(1987),Consumer behavior,NJ: Englewood Cliffs.

Sen, S., \& Lerman, D. (2007). Why are you telling me this? An examination into negative consumer reviews on the Web. Journal of interactive marketing, 21(4), 76-94.

Smith, R. B., \& Moschis, G. P. (1984). Consumer socialization of the elderly: An exploratory study. Advances in Consumer Research, 11(1), 548-552.

Steinberg, B. (2007).Verizon scores coveted 'Gossip Girl' Integration Deal,' Adage. http://adage.com/article/madisonvine-news/verizon-scores-coveted-gossip-girlintegration-deal/121256/

Sung, Y., \& de Gregorio, F. (2008). New brand worlds: College student consumer attitudes toward brand placement in films, television shows, songs, and video games. Journal of Promotion Management, 14(1), 85-101.

The Cab (2012), Time-Shifting in 2012, Cabletelevision Advertising Bureau. New York, NY.

Ward, S., \& Wackman, D. (1971). Family and media influences on adolescent consumer learning. American Behavioral Scientist. 14(3), 415.

Ward, S. (1974). Consumer socialization.Journal of Consumer Research. 1(2), 1-17. 
Weinberger, J., \& O'Dell, J. (2012). Primetime shows with the most product placement 2011. CNBC.COM http://www.cnbc.com/

Weinberger, J., \&Davis, L. (2005).Exploring the WOW in online auction feedback. Journal of Business Research, 58 (November), 1609-1621.

Xia, W., Chunling, Y., \& Yujie, W. (2012). Social Media Peer Communication and Impacts on Purchase Intentions: A Consumer Socialization Framework. Journal of Interactive Marketing (Mergent, Inc.), 26(4), 198-208.

Zajonc, R.B. (1968).Attitudinal effects of mere exposure.Journal of Personality and Social Psychology Monograph Supplement, 9(2), 1-27.

Zhu, F., \& Zhang, X. (2010). Impact of online consumer reviews on sales: The moderating role of product and consumer characteristics. Journal of Marketing, 74(2), 133-148. 